\title{
Analisis Integrasi Pasar Ikan Cakalang di Kabupaten Halmahera Selatan, Provinsi Maluku Utara
}

\section{Analysis of Cakalang Fish Market Integration in South Hamlahera District, Nort Moluccas Province}

\author{
Fauji Yamin $^{1 *}$, Anna Fariyanti ${ }^{1}$, Siti Jahroh ${ }^{1}$ \\ ${ }^{1}$ Departemen Agribisnis, Fakultas Ekonomi dan Manajemen IPB University \\ *E-mail : faujiyamin16@gmail.com
}

\begin{abstract}
This study was aimed to analyze the integration of vertical cakalang fish markets at the fishermen level, wholesalers, and retailers in Ternate city and Bitung city. Monthly time series data for the 2015-2019 period were used for this research. The analytical method used was Johansen's cointegration, Granger Causality and Vector Error Correction Model (VECM). The results showed that there is a long-term co-integration relationship among the variable prices on the levels of fishermen, wholesalers, and Ternate City retailers and Bitung City retailers. Based on the results of long-term VECM testing, the retail market in Ternate City and South Halmahera Regency Wholesale Market are tightly integrated. Whereas in the retail market of the Bitung city and the cakalang market at the fishermen level are cointegrated very weakly where every price change in the Ternate retail market will negatively affect prices at the level of Bitung city fishermen and retailers. In the short term, price formation at the fishermen level is only influenced by prices at Ternate retailers and not influenced by prices at the level of wholesalers and retailers in Bitung City.
\end{abstract}

Keywords: Johansen Test, Granger causality, Vertikal Integration, VECM

Disubmit : 14 Mei 2020, Diterima: 17 Juni 2020, Disetujui : 27 Oktober 2020

\section{PENDAHULUAN}

Komoditas tuna dan cakalang memilki nilai ekonomis penting yang tersebar hampir di seluruh wilayah perairan Indonesia (Firdaus 2019). Kontribusi TCT terhadap PDRB Indonesia memiliki kontribusi mencapai 14.69 persen dibawah udang sebesar 3.9 persen (KKP 2019). Potensi pengembangan perikanan tangkap Tuna Cakalang dan Tongkol (TCT) di Provinsi Maluku Utara sangat potensial. Wilayah yang masuk dalam WPNRI 715,716 dan 717 merupakan wilayah produksi tuna Nasional yang masuk dalam Rencana Pengelolaan Perikanan Tuna Cakalang dan Tongkol (RPP-TCT) lewat Keputusan Menteri Kelautan dan Perikanan Nomor 107/KEPMEN-KP/2015. Volume produksi TCT Maluku Utara pada WPP 715 tahun 2018, sebesar 174.730 ton dari 286.629.486 ton atau setara dengan $60.96 \%$ dari total keseluruhan hasil tangkapan di WPPNRI 715, (DKP Maluku Utara 2019).

Salah satu sentra perikanan tangkap di Maluku Utara ialah Kabupaten Halmahera Selatan dengan rata-rata volume produksi periode 2016-2018 sebesar 55.930 ton pertahun atau menyumbang $19.4 \%$ produksi perikanan tangkap Provinsi Maluku Utara dengan tingkat pertumbuhan sebesar $26.31 \%$ (BPS 2019). Kontribusi sektor ini pada PDRB sebesar $23.39 \%$ tertinggi dibanding sektor lain. Karateristik khusus lainya ialah Kabupaten Halmahera Selatan berada tepat di Wilayah Pengelolaan Perikanan (WPP 715) yang didorong pemerintah daerah menjadi pusat Lumbung Ikan Nasional (LIN) dan sentra perikanan berbasis industri. 
Komoditas utama hasil tangkap di Kabupaten Halmahera Selatan ialah ikan cakalang dengan laju pertumbuhan produksi selama periode 2017-2018 sebesar 11,3\% dengan kontribusi produksi $80.13 \%$ dari total produksi TCT. Hasil tangkapan tersebut di jual segar maupun beku ke pasar lokal, industri perikanan, serta konsumen di Kota Ternate Bitung, Manado, Surabaya, dan Jakarta. Beragamnya saluran pemasaran tersebut menyebabkan harga ikan cakalang lebih berfluktuasi di tingkat konsumen dibanding tingkat nelayan sehingga menjadikan pemasaran tidak efisien. Menurut Nurmalima et al. (2013) sistem pemasaran yang efisien dapat di lihat dari tingkat harga dan stabilisasi harga.

Fluktuasi harga merupakan isu sentral yang dihadapi oleh usaha perikanan tangkap di lokasi penelitian. Fluktuasi harga ikan segar merupakan salah satu penyumbang inflasi di Provinsi Maluku Utara (Bank Indonesia, 2018). Perubahan harga yang terjadi di tingkat konsumen akan direspons dengan cepat oleh lembaga pemasaran sehingga dapat mengambil keputusan yang tepat dan pasar menjadi lebih efisien (Asmara \& Ardhiani, 2010). Namun, fluktuasi harga seringkali lebih merugikan nelayan daripada pedagang karena pedagang dapat mengatur waktu penjualan untuk mendapatkan harga yang lebih menguntungkan (Irawan, 2007).

Perubahan-perubahan harga yang terjadi ditingkat konsumen tidak ditransmisikan dengan baik ketingkat nelayan. Sehingga, jika terjadi perubahan harga ditingkat konsumen maka perubahan harga ditingkat konsumen tidak sebesar perubahan harga ditingkat produsen. Zunaidah et al. (2015) mengungkapkan bahwa perubahan harga yang tidak berjalan seimbang antara pasar konsumen dengan nelayan menunjukan transmisi harga antar lembaga pemasaran masih rendah. Faktor yang menyebabkan adanya transmisi harga antar lembaga pemasaran ialah rendahnya informasi sehingga menyebabkan teradjinya asimetris informasi.

Integrasi pasar merupakan suatu ukuran yang menunjukkan seberapa jauh perubahan harga yang terjadi dipasar acuan akan menyebabkan terjadinya perubahan harga pada pasar pengikutnya, (Asmarantaka, 2014). Kelancaran arus informasi merupakan indikator penting pemasaran yang efisien dan terintegrasi. Apalagi, wilayah produksi yang berbasis kepulauan memiliki kendala terutama dalam akses informasi yang memadai, sehingga jika arus informasi pasar berjalan baik maka dapat meminimalisir terjadinya asimetris informasi. Integrasi pasar yang sempurna adalah fenomena yang sangat penting untuk pertimbangan manajemen sistem pemasaran yang efisien karena memiliki pengaruh yang cukup besar untuk memperoleh keuntungan maksimum bagi produsen, konsumen dan pedagang dalam rantai pemasaran (Paul \& Sinha, 2015). Berdasarkan uraian diatas, Penelitian ini penting dilakukan sebagai solusi bagi nelayan, industri, lembaga pemasaran dan pemerintah sebagai solusi dan gambaran kondisi pasar ikan cakalang sehingga dapat mengambil kebijakan yang dapat meningkatkan kesejateraan. Tujuan penelitian ini ialah Analisis integrasi vertikal pasar ikan cakalang di Kabupaten Halmahera Selatan.

\section{METODE PENELITIAN}

\section{Lokasi Penelitian, Jenis dan Sumber Data}

Penelitian ini dilakukan di Kabupaten Halmahera Selatan Provinsi Maluku Utara. Waktu penelitian yaitu bulan September-November 2019. Data yang digunakan dalam penelitian ini ialah data sekunder berupa time series bulanan periode Tahun 2015-2019 yang diperoleh dari Kementrian Kelautan dan Perikanan, Badan Pusat Statistik Kota Ternate, Badan Pusat Statistik Kota Bitung, Badan Pusat Statistik Kabupaten Halmahera Selatan, Pusat Pelabuhan perikanan (PPI) Bastiong Kota Ternate, PPP Bacan Kabupaten Halmahera Selatan, Dinas Perindustrian, Koperasi dan UMKM Kabupaten Halmahera Selatan dan publikasi lainnya yang mendukung penelitian ini.

\section{Metode Analisis Data}

Analisis data dalam penelitian ini menggunakan Model VAR (Vector Autoregressive)/VECM (Vector Error Correction Model) untuk menganalisis ada tidaknya integrasi vertikal pasar produsen, pedagang grosir, dan pedagang eceran sebagai pasar acuan. Metode analisis yang digunakan ialah : 


\section{Uji Stasioner}

Data time series umumnya tidak stasioner. Data yang tidak stasioner akan menghasilkan estimasi parameter yang semu (suporius regression). Uji stasioner pada penelitian ini menggunakan uji akar unit ADF (Augmented Dickey-Fuller) dengan melakukan perbandingan nilai statistik ADF dengan nilai kritisnya distribusi statistik Mackinnon.

\section{Uji Kointegrasi}

Uji Kointegrasi menunjukan adanya suatu hubungan panjang antara variabel untuk menentukan apakah variabel-variabel yang terstasioner terintegrasi atau tidak. Pengujian kointegrasi dapat dilakukan dengan Eangler-Grager Test, CRDW test dan Johansen Cointegration Test. Pengujian kointegrasi penelitian ini akan menggunakan Johansen Cointegration Test.

\section{Uji Kausalitas Granger}

Uji kausalitas digunakan untuk melihat ada atau tidaknya hubungan kausalitas antara dua variabel.Adapun uji kausalitas yang digunakan pada penelitian integrasi vertikal yaitu Granger Causality. Dimana, kekuatan prediksi dari informasi sebelumnya dapat menunjukkan adanya hubungan kausalitas antara y dan $\mathrm{x}$ dalam jangka waktu lama.. Persamaan matematis sebagai berikut:

$$
\begin{gathered}
\mathrm{Y}_{\mathrm{t}}=\sum_{\mathrm{i}=0}^{\mathrm{n}}=0 \mathrm{a}_{\mathrm{i}} \mathrm{X}_{\mathrm{t}-1}+\sum_{\mathrm{j}=1}^{\mathrm{n}} \beta_{\mathrm{i}} \mathrm{Y}_{\mathrm{t}-1}+\mathrm{u}_{1 \mathrm{t}} \cdots \\
\mathrm{Y}_{\mathrm{t}}=\sum_{\mathrm{i}=\mathrm{i}}^{\mathrm{n}}=\lambda_{\mathrm{i}} \mathrm{X}_{\mathrm{t}-\mathrm{i}}+\sum_{\mathrm{j}=1}^{\mathrm{n}} \delta_{j} \mathrm{Y}_{\mathrm{t}-\mathrm{j}}+\mathrm{u}_{1 \mathrm{t}} \cdots
\end{gathered}
$$

Hipotesis :

$\mathrm{H}_{0}$ : Tidak ada kausalitas

$\mathrm{H}_{1}$ : Ada kausalitas

\section{Uji Vector Error Corection Model (VECM)}

Model VAR menyediakan cara sistematis untuk menangkap perubahan yang dinamis dalam multiple time series, serta memiliki pendekatan yang kredibel dan mudah dipahami bagi pendeskripsian data, peramalan, inferensi struktural, dan analisis kebijakan, Stock dan Watson (2001) dalam Firdaus (2011). Adapun model VAR/VECM yang digunakan dalam penelitian ini sebagai berikut :

$$
\Delta \mathrm{y}_{\mathrm{t}}=\mu_{0 \mathrm{x}}+\mu_{1} \mathrm{x} \mathrm{t}+\pi_{\mathrm{x}} \mathrm{y}_{\mathrm{t}}+\sum_{i=1}^{k-1} \mathrm{Ik} \Delta \mathrm{y}_{\mathrm{t}-1}+\varepsilon \mathrm{t} \ldots
$$

Dimana ;

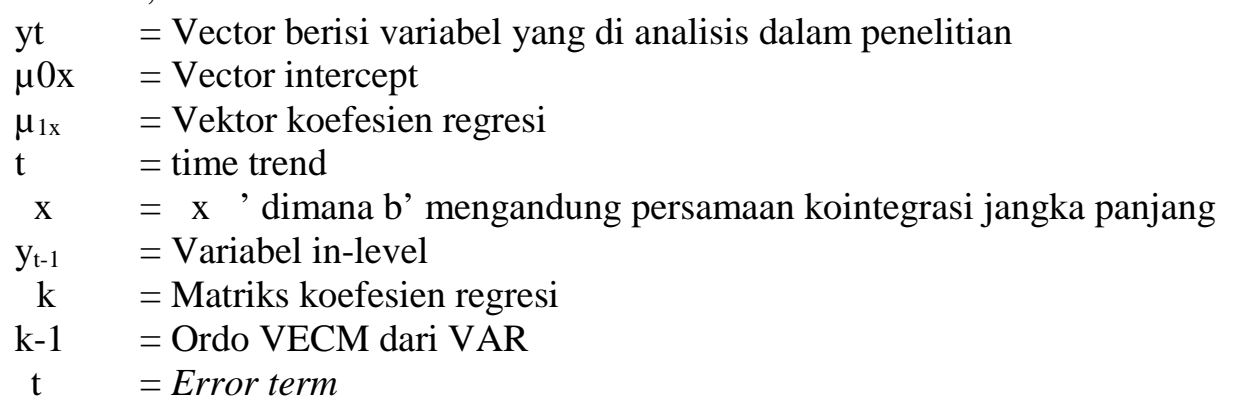

\section{HASIL DAN PEMBAHASAN}

\section{Analisis Integrasi Vertikal}

Analisis integrasi vertikal di latarbelakangi perbedaan harga yang terbentuk ditingkat produsen dan lembaga pemasaran selanjutnya. Analisis integrasi akan melihat keterpaduan antara harga di tingkat lembaga pemasaran, dimana penentuan-penentuan lembaga pemasaran tersebut berdasarkan hasil analisis saluran pemasaran pada efisiensi operasional.

\section{Uji Stasioner}

Berdasarkan hasil pengujian stasioner menggunakan Augment Dickey-Fuller Test pada tingkat level I (0), menemukan bahwa variabel harga ikan cakalang di tingkat pedagang pengecer Kota Bitung tidak Hal 60 Volume 4, Nomor 2,Tahun 2020 
stasioner dimana nilai ADF statsistik lebih besar dari nilai kritis Mc-Kinnon atau probabilitas lebih dari 5 persen (0.2375). Karena data tidak stasioner, maka perlu dilakukan pengujian pada tingkat first difference. Berdasarkan hasil pengujia pada ordo (I) semua variabel penelitian sudah stasioner sehingga pengujian lanjutan dapat dilakukan,

Tabel 1. Uji stasioner pada tingkat level

\begin{tabular}{lccl}
\hline \multicolumn{4}{c}{ Uji tingkat Level } \\
\hline Variabel & Critival Value 5\% & T-stat & Prob $^{*}$ \\
\hline Nelayan & -2.913549 & -4.683554 & 0.0003 \\
Pedang grosir & -2.915522 & -4.128287 & 0.0019 \\
EceranTernate & -2.913549 & -4.577965 & 0.0005 \\
Eceran Bitung & -2.913549 & -2.120748 & 0.2375 \\
\hline \multicolumn{4}{c}{ Uji First Diffrence } \\
\hline Nelayan & -3492149 & -10.39884 & 0.0000 \\
Pedagang Grosir & -3.496960 & -6.044217 & 0.0000 \\
Eceran Ternate & -3.492149 & -11.57426 & 0.0000 \\
Eceran Bitung & -3.493692 & -7812985 & 0.0000 \\
\hline
\end{tabular}

\section{Uji Kointegrasi}

Uji Kointegrasi bertujuan untuk menganalisis adanya hubungan jangka panjang antar variabel penelitian. Penelitian ini menggunakan pengujian Johansen Cointegration Test dengan membandingkan nilai Trace Statistic atau nilai maximum eigen dengan nilai kritis pada taraf nyata 5\%. Apabila nilai Trace Statistic lebih besar dari nilai kritis maka terdapat hubungan jangka panjang atau variabel terkointegrasi. Berdasarkan hasil analisis pada Tabel 1, terdapat hubungan kointegrasi jangka panjang antara harga ikan cakalang di tingkat nelayan (Kabupaten Halmahera Selatan), grosir (Kabupaten Halmahera Selatan), pedagang eceran (Kota Ternate) dan pedagang eceran (Kota Bitung). Hal ini ditunjukan oleh nilai trace statistic sampai pada tingkat signifikansi 5\% dimana terdapat 3 persamaan kointegrasi. Sehingga analisis yang digunakan dalam penelitian ini menggunakan Vector Error Correction Model (VECM). Berikut hasil perhitungan uji Kointegrasi

Tabel 2 Uji Kointegrasi Johansen

\begin{tabular}{lcc}
\hline Jumlah persamaan & Nilai Trace Statistic & Nilai kritis (5 persen) \\
\hline None ${ }^{*}$ & 57.87912 & 47.85613 \\
At Most $1 *$ & 31.83956 & 29.79707 \\
At most 2 & 15.75298 & 15.49471 \\
Atmost 3 & 2.522474 & 3.8141466 \\
\hline
\end{tabular}

\section{Hasil Estimasi Vector Error Correction Model (VECM)}

\section{Kointegrasi Jangka Panjang}

Berdasarkan hasil analisis kointegrasi jangka panjang menunjukan bahwa, harga ditingkat grosir memiliki pengaruh positif signifikan terhadap harga di tingkat eceran Kota Ternate sebesar 7.23 persen. Dimana, jika terjadi perubahan harga di tingkat grosir sebesar 1 persen maka terjadi kenaikan harga di tingkat pasar eceran Kota Ternate sebesar 7.2 persen begitu juga sebaliknya. Sementara hubungan jangka panjang yang terjadi antar pedagang pengecer Kota Ternate dengan nelayan maupun pedagang pengecer Kota Bitung tidak terintegrasi. Integrasi yang terjadi antar ketiga lembaga tersebut bersifat negatif dimana setiap kenaikan 1 persen ditingkat pasar acuan menyebabkan penurunan harga sebesar sebesar 0.7 persen (Bitung) dan 5 persen (Nelayan). Gandhi dan Nambodiri (2002) mengungkapkan, tidak terintegrasinya pasar dalam jangka panjang disebabkan karena kondisi 
permintaan dan penawaran dalam pasar yang berlangsung sangat cepat. Menurut, Fatin et, al (2020) kondisi tidak terintegrasinya harga ditingkat produsen dan konsumen dapat dapat membebani petani karena tidak dapat menentukan harga.

Tabel 3 Uji Kointegrasi jangka panjang

\begin{tabular}{llllll}
\hline \multirow{2}{*}{$\begin{array}{l}\text { Persamaan } \\
\text { Kointegrasi }\end{array}$} & Eceran & Pedagang & Variabel Harga Ikan Cakalang \\
& Ternate & Grosir & Eceran Bitung & Nelayan & C \\
\hline Kointegrasi 1 & 1.0000 & 7.232310 & -0.718945 & -5.131371 & -56551.22 \\
& & $(1.31045)$ & $(0.021394)$ & $(1.22442)$ & \\
& & {$[5.51895]^{*}$} & {$[-3.36052]^{*}$} & {$[4.19087]^{*}$} & \\
\hline
\end{tabular}

Ket : angka dalam [ ] adalah nilai statistic, ${ }^{*}$ adalah signifikansi pada taraf nyata 5\%, nilai $\mathrm{t}(\alpha=5 \%)=1.673$

\section{Kointegrasi Jangka Pendek}

Tahap berikutnya ialah menganalisis output VECM berupa vector koreksi kesalahan (Error Correction term). Nilai koreksi kesalahan akan menunjukkan penyesuaian harga dari keseimbangan jangka pendek menuju keseimbangan jangka panjang. Hasil analisis data kointegrasi jangka pendek yang disajikan pada Tabel 3 menunjukkan bahwa terdapat dua koreksi kesalahan yang signifikan pada taraf nyata 5\% yaitu sebesar -0.206 pada tingkat harga eceran di Kota Ternate dan $-0.137 \%$ di tingkat grosir.

Berdasarkan hasil estimasi jangka pendek, perubahan harga di tingkat pedagang eceran Kota Ternate saat ini dipengaruhi oleh harganya sendiri pada periode bulan pertama sebesar $-0.206 \%$, dan harga di tingkat pedagang grosir Kabupaten Halmahera Selatan pada periode bulan pertama sebesar $1.37 \%$. Artinya jika terjadi kenaikan harga sebesar 1 persen di tingkat grosir maka terjadi peningkatan harga di tingkat pedagang eceran Kota Ternate sebesar 1.37\%. Selain itu, pembentukan harga juga di pengaruhi oleh harga di tingkat nelayan namun memiliki nilai pengaruh negatif yang berarti bahwa perubahan harga di tingkat pedagang pengecer tidak tertransmisi dengan baik ke tingkat nelayan. Hasil ini sesuai dengan hasil kointegrasi jangka panjang dimana terdapat hubungan positif antara harga di tingkat pengecer Kota Ternate dengan pedagang grosir dan sebaliknya terdapat hubungan negatif antara harga pedagang eceran Kota Ternate dengan harga di tingkat nelayan. Tidak terintegrasinya harga di tingkat pedagang eceran dengan harga di tingkat produsen menunjukkan bahwa perubahan harga tidak diteruskan ke tingkat produsen sehingga produsen tidak diuntungkan dalam kenaikan harga, (Nuraeni et al. 2015)

Tabel 4 Kointegrasi jangka pendek harga di tingkat produsen, grosir dan eceran.

\begin{tabular}{lcccc}
\hline Error Correction: & Eceran Ternate & Pedagang Grosir & Eceran Bitung & Nelayan \\
\hline CointEql & -0.206339 & -0.137772 & 0.072476 & -0.019692 \\
& $(0.10593)$ & $(0.04333)$ & $(0.07281)$ & $(0.04548)$ \\
D(Eceran Ternate(-1)) & {$[1.94797]^{*}$} & {$[-3.17944]^{*}$} & {$[0.99530]$} & {$[-0.43297]$} \\
& -0.412122 & 0.158150 & 0.158685 & 0.110697 \\
D(Eceran Ternate(-2)) & $(0.15055)$ & $(0.06159)$ & $(0.10348)$ & $(0.06464)$ \\
& {$[-2.73749]^{*}$} & {$[2.56797]^{*}$} & {$[1.53345]$} & {$[1.71250]^{*}$} \\
D(Pedagang Grosir(-1)) & -0.206968 & 0.126295 & 0.105775 & 0.021086 \\
& $(0.14717)$ & $(0.06021)$ & $(0.10116)$ & $(0.06319)$ \\
D(Pedagang Grosir(-2)) & {$[-1.40628]$} & {$[2.09769]^{*}$} & {$[1.04558]$} & {$[0.33368]$} \\
& 1.739526 & 0.401572 & -0.891829 & 0.110084 \\
& $(0.67300)$ & $(0.27531)$ & $(0.46261)$ & $(0.28897)$ \\
D(Eceran Bitung(-1)) & {$[2.58474]^{*}$} & {$[1.45861]$} & {$[-1.92784]^{*}$} & {$[0.38095]$} \\
& 0.641161 & 0.430484 & -0.590882 & 0.285145 \\
D(Eceran Bitung(-2)) & $(0.62484)$ & $(0.25561)$ & $(0.42950)$ & $(0.26829)$ \\
& {$[1.02613]$} & {$[1.68415]^{*}$} & {$[-1.37575]$} & {$[1.06283]$} \\
& -0.171682 & 0.015743 & 0.043842 & 0.088521 \\
Hal 62 Volume & $(0.20023)$ & $(0.08191)$ & $(0.13763)$ & $(0.08597)$ \\
& {$[-0.85743]$} & {$[0.19216]$} & {$[0.31854]$} & {$[1.02964]$} \\
& -0.297970 & 0.011626 & -0.277309 & -0.029683 \\
& $(0.20069)$ & $(0.08210)$ & $(0.13795)$ & $(0.08617)$ \\
& {$[-1.48471]$} & {$[0.14161]$} & {$[-2.01019]^{*}$} & {$[-0.34446]$} \\
\hline
\end{tabular}

Hal 62 Volume 4, Nomor 2,Tahun 2020 


\begin{tabular}{lcccc}
\hline $\mathrm{D}($ Nelayan(-1) & -1.099131 & -0.641228 & 0.914652 & -0.466845 \\
& $(0.58277)$ & $(0.23840)$ & $(0.40058)$ & $(0.25023)$ \\
& {$[1.88604]^{*}$} & {$[-2.68969]^{*}$} & {$[2.28329]^{*}$} & {$[-1.86568]^{*}$} \\
$\mathrm{D}($ Nelayan(-2)) & -0.959904 & -0.312801 & 0.645276 & -0.407751 \\
& $(0.56283)$ & $(0.23025)$ & $(0.38688)$ & $(0.24167)$ \\
& {$[1.70548]^{*}$} & {$[-1.35855]$} & {$[1.66790]$} & {$[-1.68724]^{*}$} \\
\hline
\end{tabular}

Ket : angka dalam [ ] adalah nilai statistik, * adalah signifikansi pada taraf nyata $5 \%=1.673$.

Pembentukan harga di tingkat pedagang grosir dipengaruhi oleh harganya sendiri pada periode dua bulan sebelumnya $0.43 \%$ dan di pengaruhi secara positif oleh harga di tingkat pedagang grosir Kota Ternate selama dua periode sebesar 0.15 dan $0.12 \%$. Hal ini berarti bahwa pasar grosir dan eceran di Kota Ternate terintegrasi baik dalam janga pendek maupun dalam jangka panjang. Selain itu, pembentukan harga juga di oengaruhi oleh harga di tingkat nelayan akan tetapi memiliki pengaruh yang negatif. Hasil ini sejalan Nuraeni et al. 2015 dan Fatin et al. (2020) yang menemukan ada hubungan positif antar pengecer dan grosir. Sedangkan hubungan antar nelayan dengan pedagang bersifat negatif. Kondisi ini disebabkan karena nelayan tidak memiliki hubungan langsung dengan pedagang grosir melainkan terhubung dengan pedagang perantara dalam melakukan pemasaran ikan cakalang.

Pembentukan harga di pasar tingkat eceran Kota Bitung di pengaruhi oleh harga di tingkatnya sendiri periode dua bulan sebelumnya $-0.277 \%$, harga di tingkat pedagang grosir periode satu bulan sebelumnya sebesar $-0.891 \%$ yang menunjukan bahwa dalam jangka pendek tidak ada integrasi antar kedua tingkat pasar tersebut. Sementara, pembentukan harga sangat dipengaruhi oleh harga di tingkat nelayan dimana jika terjadi perubahan harga sebesar 1 persen di tingkat nelayan maka terjadi perubahan harag di tingkat pedagang grosir Kota Bitung sebesar 0.91\%. Hasil ini sesuai dengan hasil kointegrasi jangka panjang dimana pembentukan harga di tingkat pedagang eceran Kota Bitung dipengaruhi oleh harga di tingkat nelayan.

Pembentukan harga di tingkat nelayan dipengaruhi oleh harganya sendiri pada satu bulan sebelumnya sebesar $-0.46 \%$ dan dua bulan sebelumnya sebesar $-0.40 \%$. Sementara, dalam jangka pendek pembentukan harga di tingkat nelayan dipengaruhi oleh harga di tingkat pasar eceran Kota Ternate periode satu bulan sebelumnya sebesar $0.40 \%$. Dalam jangka pendek, harga di tingkat nelayan tidak terintegrasi dengan pasar di tingkat pedagang grosir dan pedagang eceran Kota Bitung. Tidak terintegrasi antar pasar di tingkat nelayan dengan harga di tingkat grosir dan pedagang eceran menunjukan bahwa nelayan merupakan pihak yang tidak diuntungkan dalam sistem pemasaran hasil tangkap dan hanya berperan sebagai price taker sedangkan pedagang memiliki kekuatan dalam penentuan harga.

Menurut Soukotta (2015), perubahan harga ikan di tingkat pengecer berpengaruh nyata terhadap harga di tingkat produsen akan tetapi, perbedaan besaran kenaikan harga tidak terintegrasi sempurna karena kenaikan harga satu unit ditingkat pengecer diikuti kenaikan harga yang lebih kecil di tingkat produsen. Kerjasama yang kuat (patron klien) antara nelayan dengan pedagang di lokasi penelitian diduga menyebabkan nelayan tidak mampu menentukan harga mengikuti perkembangan harga yang terbentuk di tingkat konsumen. Menurut Tain (2011) nelayan merupakan pihak yang terikat dengan pedagang perantara sebagai agen kreditur sehingga berpapun harga yang dibayarkan akan diterima. Selain itu, walaupun nelayan melakukan penjualan Tempat Pelangan Ikan (TPI) PPP Bacan akan tetapi harga yang terbentuk tidak mengikuti mekanisme pelelangan melainkan ditetapkan oleh pedagang maupun industri perikanan.

\section{Uji Kausalitas Grangger}

Berdasarkan hasil uji kausalitas dilakukan untuk mengetahui variabel yang berpengaruh terhadap perubahan variabel lain. Hasil uji menunjukan bahwa pada tingkat grosir dan eceran Kota Ternate terdapat kausalitas satu arah yaitu harga di tingkat eceran dipengaruhi harga di tingkat grosir (probabilitas <0.05) yang menjukan pasar di tingkat grosir dominan mempengaruhi harga di tingkat pedagang pengecer namun kondisi ini tidak terjadi dua arah dan bersifat independent. Selain itu, harga eceran Kota Ternate juga mempengaruhi harga eceran Kota Bitung $<10$ persen secara independent. Sementara, pasar tingkat nelayan tidak memiliki hubungan kausalitas satu arah maupun dua arah dengan tingkat grosir maupun konsumen. Maka dapat di simpulkan bahwa integrasi pasar ikan cakalang di Kabupaten Halmahera Selatan sangat lemah. Dimana, perubahan-perubahan harga di tingkat konsumen tidak tertransmisi dengan baik tingkat 
nelayan. Adapun uji kausalitas dilakukan menggunakan Granger Causality Test disajikan pada Tabel 4 sebagai berikut :

Tabel 5 Analisis kausalitas Grangger

\begin{tabular}{lcc}
\hline \multicolumn{1}{c}{ Hipotesis alternative $\left(\mathrm{H}_{1}\right)$} & F-Statistic & Probabilitas \\
\hline Harga eceran Ternate memengaruhi harga grosir & 0.26738 & 0.7664 \\
Harga grosir memengaruhi harga eceran Ternate & 2.70488 & $0.0765^{*}$ \\
\hline Harga eceran bitung memengaruhi harga grosir & 0.31364 & 0.7322 \\
Harga grosir memengaruhi harga eceran Bitung & 0.16171 & 0.8511 \\
\hline Harga nelayan memengaruhi harga grosir & 0.89893 & 0.4134 \\
Harga grosir memengaruhi harga nelayan & 0.00175 & 0.9983 \\
\hline Harga eceran Bitung memengarhi harga eceran Ternate & 0.23299 & 0.7930 \\
Harga eceran Ternate memengaruhi harga eceran Bitung & 5.68105 & $0.0059^{*}$ \\
\hline Harga nelayan memengaruhi harga eceran Ternate & 0.82148 & 0.4455 \\
Harga eceran Ternate memengaruhi harga nelayan & 1.41724 & 0.2518 \\
\hline Harga nelayan memengaruhi harga eceran Bitung & 0.68542 & 0.5085 \\
Harga eceran Bitung memengaruhi harga nelayan & 0.55521 & 0.5774 \\
\hline
\end{tabular}

Ket : tanda * adalah signifikan pada taraf nyata $10 \%$.

\section{Implikasi Kebijakan}

Pasar yang tidak terintegrasi dalam jangka panjang dan jangka pendek menunjukan bahwa nelayan merupakan pihak yang tidak diuntungkan dalam sistem pemasaran hasil tangkap dan hanya berperan sebagai price taker sementara pedagang memiliki kekuatan dalam penentuan harga. Faktor yang menyebabkan nelayan masih menerima dibawah harga pasar karena pasar berbentuk persaingan tidak sempurna, asimetris informasi, serta praktek kerjasama. Sistem pelelangan di pandang penting untuk diterapkan agar pemasaran menjadi lebih efisien. Menurut Tourte dan Gaskel (2004) pasar lelang dapat memfasilitasi produsen dan pembeli dalam proses tawar-menawar. Sehingga, memungkin tercipta harga tertinggi yang terbentuk di pasar. Selain itu, kegiatan pelelangan akan memberikan informasi kepada nelayan tetang pembentukan harga yang terjadi di pasar serta menjadi acuan bagi nelayan dalam melakukan penjualan ke pedagang.

Pasar ikan cakalang di Kabupaten Halmahera Selatan tidak terintegrasi secara penuh yang berdampak pada tingkat efisiensi pemasaran dan merugikan nelayan. Pasar menjadi terintegrasi, jika ada intervensi. Dimana, dampak dari intervensi pemerintah dapat disalurkan kepada pasar-pasar lainnya sehingga kebijakan harga dapat dilakukan dengan efektif. Intervensi yang perlu dilakukan menurut Mafimisebi (2012), ialah keterserdian informasi pasar dan produksi untuk diketahui semua pihak sehingga mengurangi ketidakpastian dalam di pasar. Dampaknya, terjadi pengurangan resiko antar lembaga atau pasar dan menjadikan pemasaran menjadi efisien dimana pasar menjadi tidak terkonsentrasi dan tidak dapat dikuasai oleh beberapa pedagang.

\section{KESIMPULAN}

Berdasarkan hasil analisis integrasi, pembentukan harga yang terjadi ditigkat produsen tidak terintegrasi baik secara jangka panjang dan jangka pendek. Tidak terintegrasinya pasar ditingkat nelayan dengan pedagang grosir dan pedagang eceran disebabkan nelayan tidak memiliki pengaruh langsung dalam penetapan harga dan hanya berperan sebagai price taker dalam sistem pemasaran ikan cakalang di Kabupaten Halmahera Selatan. Sementara, uji causalitas granger menemukan, bahwa tingkat integrasi pasar yang terbentuk tidak terintegrasi secara kuat.

\section{Saran}

Berdasarkan hasil penelitian, perlu adanya perbaikan akses sarana prasarana, (jalan, angkutan darat maupun laut) guna mendukung alur distribusi pemasaran dimana pusat produksi berada di kepuluan serta perlu adanya kebijakan dan penetapan sistem lelang di Tempat Pelelangan Ikan. 


\section{DAFTAR PUSTAKA}

Asmarantaka RW. 2014. Pemasaran Agribisnis (Agromarketing). In bogor: IPB Pres.

Bank Indonesia., 2018. Kajian Ekonomi Keuangan dan Regional, Ternate (ID). Bank Indonesia

Fatin ZN, Titik E, Muliayanto SB. 2020. The Analysis Of Price and Market Integration Of Banana Commodities In Lampung, Indonesia. RJOAS 3(99).

Firdaus M. 2011. Aplikasi Ekonometrika Untuk Data dan Time Series. IPB Pres. Bogor.

Gandhi VP, Namboodiri NV. 2002. Fruit and vegetable Marketing and its Efficiency in India: a Study of Wholesale Markets in the Ahmedebad Area.

Irawan B. 2007. Fluktuasi harga, Transmisi Harga dan Marjin Pemasaran Sayuran dan Buah. Analisis Kebijakan Pertanian 5(4):p.358-373.

Mafimisebi, TE, (2012), Spatial equilibrium, market integration and price exogeneity in dry fish marketing in Nigeria: A vector auto-regressive (VAR). J. econ. finance adm. 17(33), 2012, 31-37

Nurmalina R, Rifin A, Harmini, \& Amalia DN. (2013). Kajian Pemasaran Karet Rakyat di Provinsi Jambi. Prosiding Seminar Penelitian Unggulan Departemen Agribisnis Desember 2013 2(1):135-150

Nuraeni D, Anindita R, Syafrial. 2015. Analisis Variasi Harga dan Integrasi Pasar Bawang Merah di Jawa Barat. Habitat. 26(3):163-172.

Paul RK, Sinha K. 2015. Spatial Market Integration among Major Coffe Market in India. Journal of The Indian Society Of Agricultural Statistic. 69(3):p.281-287.

Ravallion M. 1986. Testing Market Integration. American Journal of Agricultural Economics 68(1):p.102109.

Soukotta LM. 2015. Analisis Efisiensi Pemasaran Usaha Pure Siene di Kota Ambon. Jurnal Wilayah dan Lingkungan Volume 3 Nomor 1 April 2015, 15-26.

Tain, Anas. 2011. Penyebab Kemiskinan Rumah Tangga Nelayan di Wilayah Tangkap Lebih Jawa Timur. Jurnal Humanity Volume 7 No 1.

Tourte L, Gaskel M. 2004. Horticultural Auction Markets: Lingking Small Farms With Counsumer Demand. Reneable Agriculture and Food System. 19(3):129-134

Zunaidah AD, Setiawan B, Anindita R. 2015. Analisis Integrasi Pasar Apel (Kasus di Desa Sumbergo, Kota Batu, Jawa Timur). Habitat 26(3):p.183-194. 